DOI https://doi.org/10.18551/rjoas.2018-01.02

\title{
AGRICULTURAL DEVELOPMENT PLANNING BASED ON LOCAL RESOURCES IN DEPOK CITY, INDONESIA
}

\author{
Abdurahim Andi* \\ Master's Program of Public Administration, Faculty of Administrative Science, \\ University of Brawijaya, Indonesia \\ Sumartono, Hanafi Imam \\ Faculty of Administrative Science, University of Brawijaya, Indonesia \\ *E-mail: mr.andy.162@gmail.com
}

\begin{abstract}
The background of this study is that Dewa Starfruit as a local resource in Depok City is threatened with extinction. The absence of regulations that protect these local resources and high rate of land use conversion causes decreasing number of starfruit plants and production. Starfruit farmers tend to switch professions to non-agricultural occupations. In national level, the largest number of agricultural business households experienced the greatest decline in horticulture subsector by $37.4 \%$ (Agricultural Census 2013). The elected regional head has branded Depok City with the tagline "friendly city" replacing Dewa Starfruit. The government's orientation and support for Dewa starfruit is fading away. Therefore, Depok City Government, especially DKP3, need to develop local resource-based agriculture development plan in order to be able to maintain local resources while improving it for society welfare. This research uses qualitative approach. The research informants were DKP3 apparatus of Depok City, Bappeda (Regional Government) apparatus of Depok City, field officer and farmer group. Data collection techniques used in-depth interviews and documentary studies. Data analysis utilized interactive model. Research results indicate that the development of local resource-based agricultural development plans has not gone well. Despite various supporting factors, there are existing inhibiting factors which are land use conversion had never been discussed; DKP3 Depok City efforts to safeguard agricultural issues in musrenbang has not been optimal; no field data update, either by couseling workers or farmers; DKP3 Depok City prioritized RPL activity; uneducated farmers; and absence of regional head support.
\end{abstract}

\section{KEY WORDS}

Planning, agriculture, local resources, plants, agricultural business.

Public administration possesses an important role in a country. This is exhibited by the regulations dynamics and transforming organization or state institution type, officials and staff placement, organizational structure, as well as appointment and dismissal mechanism at central and regional level (Keban, 2008). According to Thoha (2010), the orientation of public administration is directed to the public interest. Due to its orientation to the public, a nation strives in such a way to serve the public (Hardiyansyah, 2011). Development is crucial in conductind programs and activities to produce something for the public interestTherefore it is necessary to apply administrative theory known as development administration. Katz (1971) as quoted by Kartasasmita (1997) suggests that development administration is correlated and involved in mobilizing resources and its allocation for development activities.

Development begins with planning stage (Tjokroamidjojo, 1995a). Conyers and Hills (1994) define planning as a continuous process that includes decisions or choices on alternatives to resources usage in achieving future objectives. Tjokroamidjojo (1995a) states that this continuous factor covers two aspects: plan formulation and implementation.

Development planning allows a region to make changes and improvements through planning by utilizing its resources to achieve the desired goals. The agricultural sector plays 
an important role in regional development. Unfortunately, the government's attention and support to the agricultural sector are considered not strict and prone to trade-offs (Hapsari, 2014). On the other hand, Indonesia's geographical condition located at the equatorial latitude provides a comparative advantage crops growth and becomes a local resource. Dewa Starfruit in Depok City is a local resource that has the potential to be developed. However, the absence of regulations protecting the local resources and the continuous land use conversion caused reduced total starfruit plants and farmers shifted to non-agricultural professions. Starfruit is included in the horticultural subsector of non-food crops, which is consumed or enjoyed by the community not as a staple food. In national level, the largest number of agricultural business households experiencing decline is in horticulture subsector at $37.4 \%$ (Agricultural Survey Year 2013). Dewa Starfruit as a local resource in Depok City would be threatened to extinct. Although Law No.41 / 2009 on Sustainable Land Farming Protection is aimed at protecting agricultural land, it does not dampen land use conversion in Depok. Likewise, Law No.13 / 2010 on Horticulture has not become a reference in the local resource-based agricultural development plan. Therefore, the Dept. of Food, Agriculture and Fisheries Dept. (DKP3) Depok needs to develop a local resource-based agricultural development plan to be able to maintain local resources while improving them for the welfare of the community.

Based on the described phenomenon, there are two problems raised in this research as follows: (1) How far is the formulation of the local resource-based agricultural development plan in Depok City; (2) What factors which support and inhibit their planning?

\section{LITERATURE REVIEW}

Tjokroamidjojo (1995b) describes the stages in a planning process includes development, programming, implementation, monitoring, and evaluation. Plan formulation is divided into a review of the circumstances, approximate circumstances, determining plan objectives, policy identification undertaken, and approval. Conyers and Hills (1994) describe the planning process as a closed cycle (Figure 1), wherein each stage there is certain goals. Therefore it is crucial to understand each stage. These stages are specified planning goals, formulate objectives, collect and analyze data, identify an alternative course of action, alternative appraisals, selection-preferred alternatives, implement, monitor and evaluate.

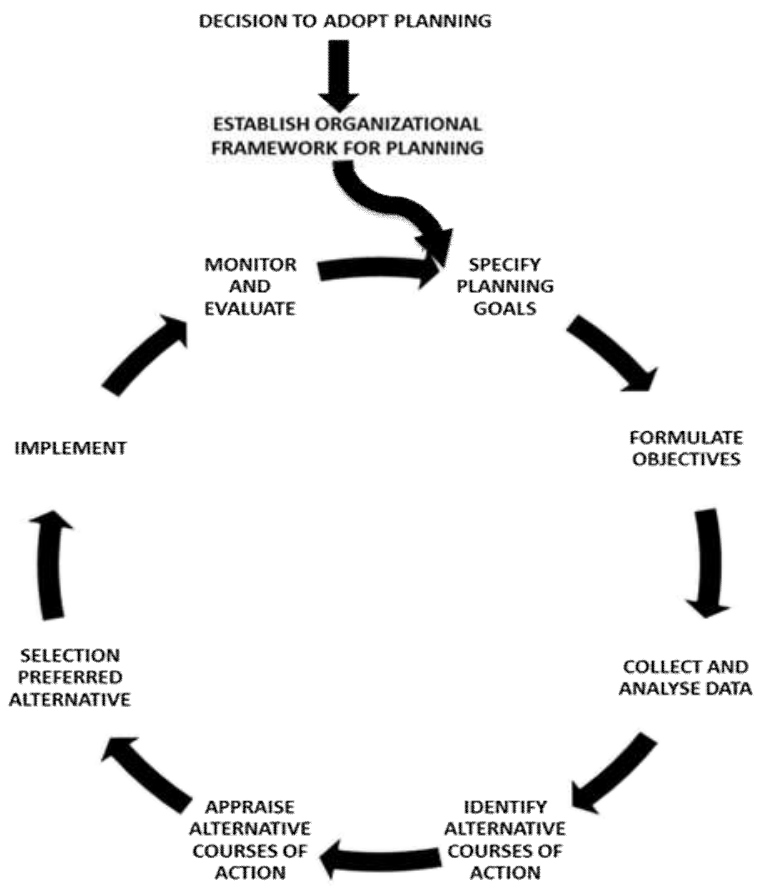

Figure 1 - Planning Process Cycle 
Law No.25 / 2004 on SPPN divide the stages of national development planning into four: plan development, establishment, controls, and evaluations. Researchers refer to the Act to describe and analyze the development of local resource-based agricultural development plans in Depok City. The stages of plan development based on the Act is the draft development; musrenbang (discussion); and constructing final draft; as well as planestablishment.

In general, the factors that support and inhibit plan development refers to the factors that affect development. These factors are the environment, human resources, planning system, technological development, and funding (Riyadi and Bratakusumah, 2004). According to Kuncoro (2004), there are two conditions contributing to planning development. Those are environmental pressure and community perspectives on the direction and meaning of development. According to Conyers and Hills (1994), government agencies are overly enjoying the administrative routine, therefore, planning targets are made only based on "guestimate" or allegations based on administrative experience alone rather than performing more accurate data analysis.

Depok city is a megapolitan area in Jabodetabek (Jakarta, Bogor, Depok, Tangerang, and Bekasi). Depok City consists area of $200.29 \mathrm{~km} 2$. It has eleven districts. Population growth is increasing every year. In 2015 the population of Depok City amounted to 2,106,102 people. It is influenced by factors of high birth rates and demographic factors that cause high migration rate into Depok City.

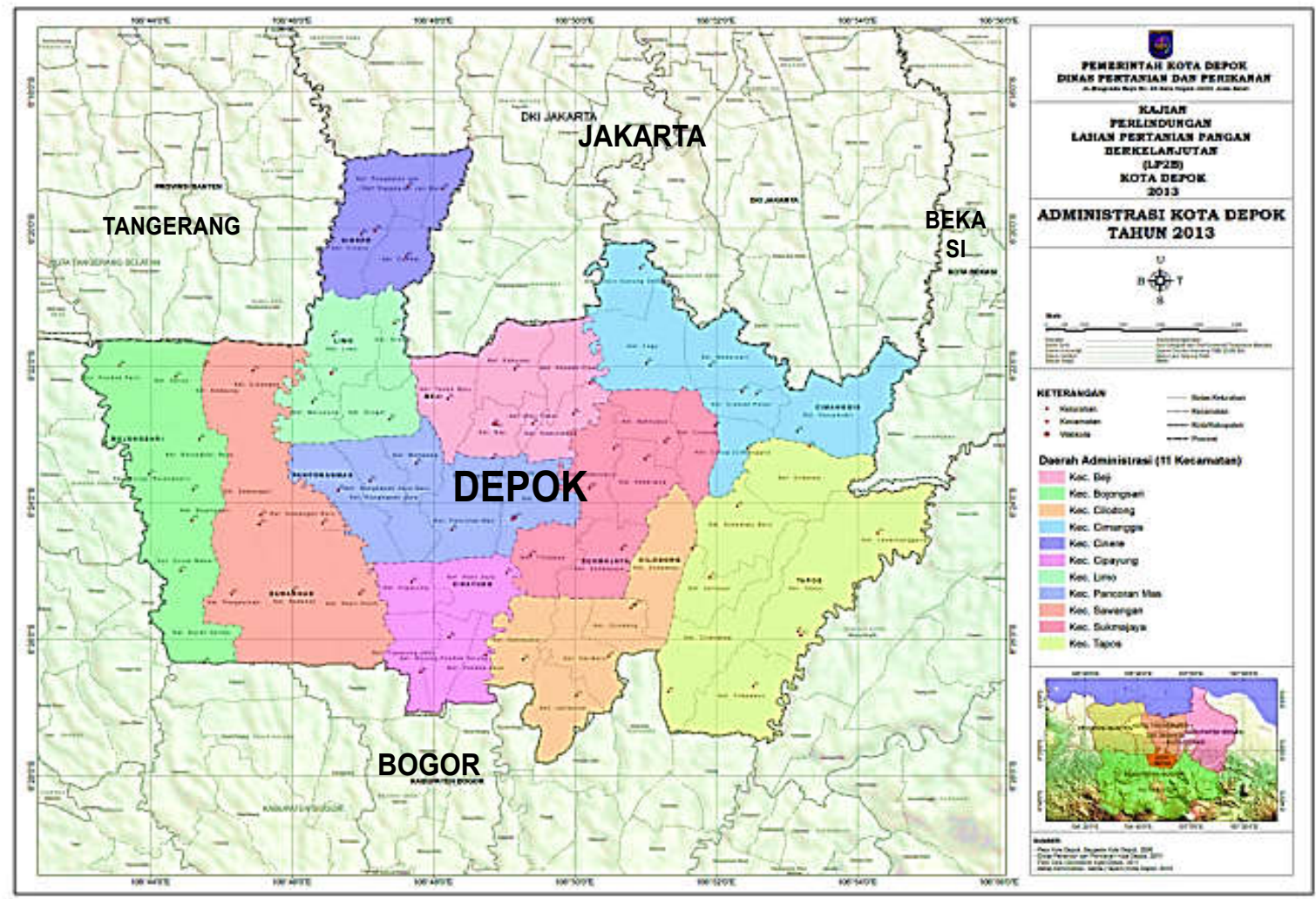

Figure 2 - Depok City Administrative Area

Land use in Depok City is dominated by 11,550 ha for settlements or $57.7 \%$ of the total area. The development of settlements in Depok City has a major impact on land functions change, especially agricultural land to non-agricultural. Another impact are farmers switching to non-agriculture proffessions due to land use conversion or sold their land to make ends meet. Depok City remains to possess farmlands despite its continually decreasing farmland, including the Dewa starfruit as exhibited in Figure 3. 


\section{METHODS OF RESEARCH}

The focus of this research is the development of local resource-based agricultural development plan in Depok City; and the factors that support and inhibit the planning. This research uses a qualitative approach. Data collection techniques used was in-depth interviews and documentary studies. Informants in this research are apparatus of Food Security, Agriculture and Fisheries Department (DKP3) Depok City; the apparatus of the Regional Development Planning and Research Agency (Bappeda) of Depok City; field officer; and farmer groups. Data analysis techniques used interactive models (Miles et al., 2014) ranging from data collection, data condensation, and conclusions.

\section{RESULTS AND DISCUSSION}

The development of local resource-based agricultural development plans uses several approaches: political approach, technocratic approach, participatory approach and top-down and bottom-up approach. The political approach refers to the vision and mission of the elected regional head as stated in Law No.23 of 2014 on Regional Government. The technocratic approach in the form of development of the initial draft that will be used as a reference in development planning discussion (musrenbang). Top-down, bottom-up and participatory approaches is conducted through musrenbang activities ranging from urban to municipal levels involving all stakeholders. Development of local resource-based agricultural development plan refers to the Depok City Regional Medium Term Development Plan (RPJMD) and Strategic Plan (Renstra) DKP3 Kota Depok.

The first stage, preparing development plan draft. In this stage, the government of Depok City held a socialization of year to date development planning (T1). The socialization was held in the first month of each beginning of the year which was facilitated by Bappeda Kota Depok (Depok City Regional Government). The following activity involved Focus Group Discussion (FGD) on strategic issues that arise in the following year (T2). Unfortunately, the issue of land use conversion does not surface and has not yet become a common agenda for completion.

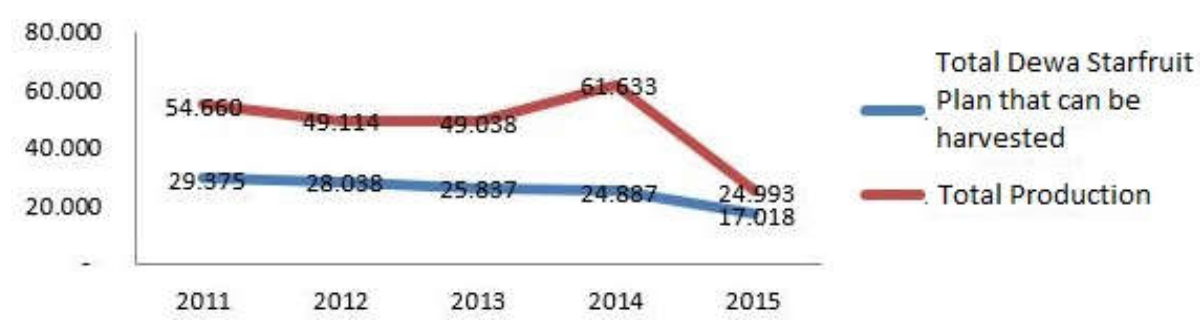

Figure 3 - Total Dewa Starfruit Plant that can be harvested and total production rate

The second stage, musrenbang activity. Musrenbang activity starts from urban village level to city level. Depok City Government has involved farmers in musrenbang activities from urban village to city level. This indicates that their existence cannot be ignored because it helped determining future agricultural development planning. At every stage of the musrenbang, agricultural issues are always proposed by farmers based on their needs. In each stage, the farmers are always accompanied by DKP3 apparatus of Depok City both structural and functional (counseling field). Nevertheless, Depok City DKP3 efforts to maintain agricultural issues are not optimally experienced by farmers. Therefore agricultural issues seem less weighty and popular than infrastructure issues. In addition, there has been no data update effort conducted by Depok City DKP3 part, especially counselors, along with the farmers on institutional information and agricultural productivity.

The third stage, forming development plan final draft. At this stage, all proposals of the development plan are sorted according to the city priority scale and future strategic issues. In its priority, DKP3 Kota Depok focuses on Sustainable Foodstuff (RPL) activities oriented towards food security programs. 
The final stage, plan establishment. Development plan establishment is carried out by City Mayor in the form of an annual city planning document.

The shortcomings of efforts described above are also augmented by the obstacles in the establishment of local resource-based agricultural development plans. These inhibiting factors are uneducated farmers and weak commitment exhibited by the regional head. Supporting factors are conducive office internal environment, educated farmers, field officers who actively counsel the farmers, compact planning team, the use of internet-based technology in planning, the latest technology in agricultural cultivation, and adequate budget.

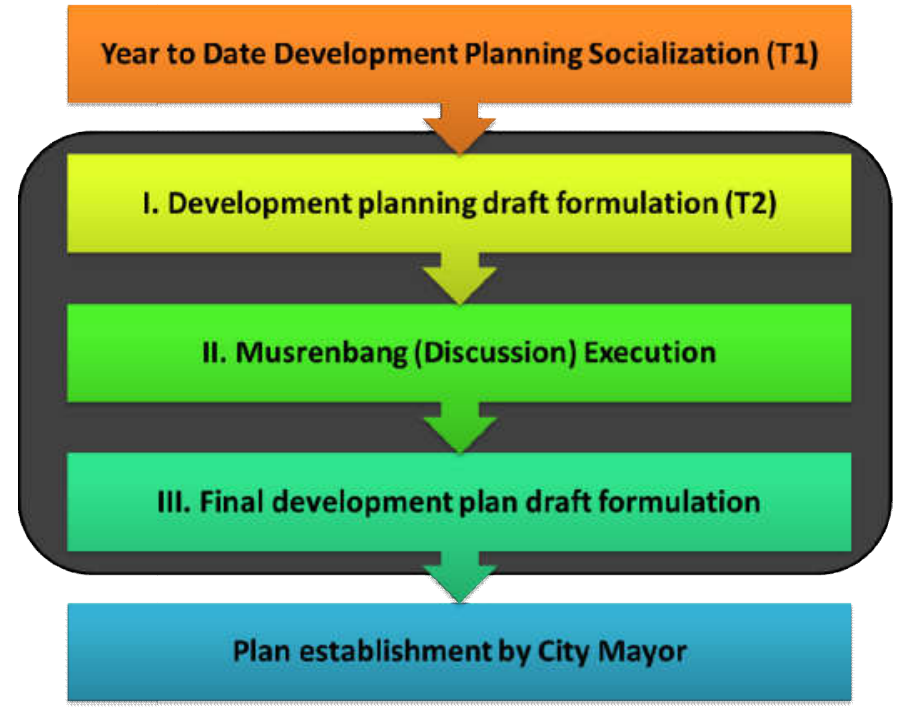

Figure 4 - Agriculture based development plan based on local resources

The development of local resource-based agricultural development plans is part of the overall development planning stage of the region. Political approach is the elaboration of the vision and mission of the elected regional head as outlined in the RPJMD of Depok City. As a result, all programs and activities are tailored based on the vision and mission. The technocratic approach is taken through FGD involving stakeholders and planning experts to prepare the initial work plan as a consideration of the development plans in the next period through musrenbang (discussion) activities. In an integrated way, a participatory, top-down and bottom-up approach is pursued in the musrenbang activities. It includes the delivery of government policies to communities. This also involved stakeholders from all elements of society as well as a selection of community aspirations to be taken and forwarded to the government.

The RPJMD and straregic plan (Renstra) of Regional Apparatus Organization (OPD) as a reference in developing local resource-based agriculture development plan contains the government's readiness to adopt future planning which according to Conyers and Hills (1994) is known as the decision to adopt planning. The RPJMD and Renstra contain objectives, targets, strategies, policy directions, programs and activities as the elaboration of the regional head's vision and mission. Conyers and Hills (1994) specify planning goals and formulate objectives exists in the mentioned development plan. Thus, DKP3 has been in a position to establish an organizational framework for planning.

In the development stage, the socialization activities of the year to date development plan provide an opportunity for the community to acknowledge target achievement. This is supported by Tjokroamidjojo's opinion (1995b) that in the planning stage it is necessary to review the situation while strengthening the organizational framework. Thus the community can propose reinforcing activity or cease unnecessary activity. After the socialization activities, the role of FGDs on strategic issues is very important to determine and predict future developments. This is in accordance with the planning stages proposed by Tjokroamidjojo (1995b) with the term "estimated circumstances to be passed". Unfortunately, 
the issue of the agricultural land conversion has not been raised as if it has not been on local governments' agenda.

Musrenbang is the most decisive stage in the development plan. This is where community involvement in planning is exhibited. Suggestions on development are delivered by various levels of society including farmers. Usually, farmers propose the availability of facilities and infrastructure to increase agricultural productivity. Nevertheless, their proposals are rarely realized. In every musrenbang forum, farmers are always accompanied by DKP3 Depok City apparatus, both structural and functional (counseling field). The assistance will be more optimal should agricultural issues is carried out continuously, ranging from urban village level to city level. In addition, data updating on farmers and their institutions have not been done jointly by Depok City DKP3, more so by counselors and farmers. Therefore every proposal put forth by the farmers carry less weight considering it lacks updated data. Therefore it is not strong enough to be maintained because all programs and activities are conducted based on data and priority scale. A proposal with strong and valid information will be prioritized over a weak proposal.

The third stage involved finalizing development plan. At this stage, all data and information on the development are collected and made priority scale based sequence. In this case, DKP3 Kota Depok prioritizes RPL activities that are more inclined to food security than agricultural cultivation. Prioritized activity focuses on activities that support the RPL in the form of home gardening. RPL activities are derivative activities of the Ministry of Agriculture of the Republic of Indonesia. In Depok City, RPL activity is limited to the use of home yard conducted by housewives. However, this activity has not been applied widely or in the form of an area called KRPL (Sustainable Food Housing Area).

The final stage, the establishment of a development plan, is set in the form of a citylevel annual planning document through a Mayor's Regulation.

The emergence of the tagline such as 'friendly city' replaces Dewa Starfruit as the city icon. Therefore it changed the orientation and support of Depok city government from local resources to other sectors. It thus signifies that the selection of programs and activities is determined through a political process (Conyers and Hills, 1994). Therefore, the support and involvement of regional heads are crucial for determining the sustainability of future planning (Fadlina, 2013; Hapsari, 2014). The development of local resource-based agricultural development plans would be better when supported by farmers. But the existence uneducated farmers will complicate the process. Because these farmers are not active in farmer groups and do not follow various agricultural activities. They have high tendency to sell or rent land. Thus land use conversion caused destruction of agricultural land due to development rate and farmers themselves to make ends meet.

The existence of factors supporting development plan is expected to encourage Depok City government, especially DKP3, as an endeavor to produce development plan based on high-quality local agricultural resources. It is expected to be able to improve the welfare of the community and at the same time maintain local resources owned.

\section{CONCLUSION AND SUGGESTIONS}

The development of local resource-based agricultural development plans is supported by a number of factors: conducive office internal environment, educated farmers, field officers who actively nurtured or provided counseling to the farmers, compact planning team, utilization of Internet-based technology, agricultural cultivation technology, and adequate budget.

However, there are several inhibiting factors. These constraints are (1) lack of discussion regarding land use conversion; (2) Unoptimal efforts to safeguard agricultural issues in Depok City DKP3 musrenbang; (3) lack of field data update, either by counseling workers or farmers; (4) DKP3 Depok City prioritized RPL activity; (5) uneducated farmers; and (6) absence of regional head support.

Based on the results of research, there are several suggestions produced to optimize plan development process. The suggestions are described as follows: protection of starfruit 
farmland in the form of regulation and compensation to farmers who are willing to maintain their respective farmlands. It could be conducted in the form of subsidy, and tax exemption; hold internal consolidation of Depok City DKP3 in endeavor to discuss agriculture issues; monthly or quarterly data updated conducted by officer and farmer. It could be conducted by crosscheck method in the field or through social media application; integration of local resources into RPL activities.

Actions to be conducted to uneducated farmers are as follows: conducting intensive guidance to encourage active participation in groups and raises awareness to defend farmland from land conversion; Depok City DKP3 encourages the activity of the farmer group leader in order to involve all its members in counseling activities; DKP3 Depok City holds a competition to choose the winner farmer which require active farmer in respective group and able to increase productivity; joint commitment between leaders and subordinates in carrying local resources with comparative advantage.

\section{REFERENCES}

1. Conyers, Diana dan Hills, Peter. (1994). An Introduction to Development Planning in The Third World. Chicester: John Wiley \& Sons.

2. Fadlina, Inneke Meilia. (2013). Perencanaan Pembangunan Pertanian Berkelanjutan di Kota Batu (Kajian tentang Pengembangan Pertanian Organik di Kota Batu). Malang: Magister IImu Administrasi Publik, Fakultas IImu Administrasi, Universitas Brawijaya.

3. Hapsari, Heilda Thauresia. (2014). Perencanaan Pengembangan Wilayah Komoditas Pertanian Tanaman Pangan dan Hortikultura di Kabupaten Pacitan dengan Pendekatan Sistem. Malang: Magister IImu Administrasi Publik, Fakultas Ilmu Administrasi, Universitas Brawijaya.

4. Hardiyansyah. (2011). Kualitas Pelayanan Publik: Konsep, Dimensi, Indikator dan Implementasinya. Yogyakarta: Gava Media.

5. Kartasasmita, Ginandjar. (1997). Administrasi Pembangunan, Perkembangan Pemikiran dan Praktiknya di Indonesia. Jakarta: Pustaka LP3ES.

6. Keban, Yeremias T. (2008). Enam Dimensi Strategis Administrasi Publik, Konsep, Teori dan Isu. Yogyakarta: Gava Media.

7. Kuncoro, Mudrajad. (2004). Otonomi dan Pembangunan Daerah: Reformasi, Perencanaan, Strategi, dan Peluang. Jakarta: Erlangga.

8. Miles, Matthew B., A. Michael Huberman, dan Johnny Saldana. (2014). Qualitative Data Analysis: A Methods SourceBook. Third Edition. California: Sage Publications, Inc.

9. Riyadi dan Bratakusumah, Deddy Supriady. (2004). Perencanaan Pembangunan Daerah: Strategi Menggali Potensi dalam Mewujudkan Otonomi Daerah. Jakarta: PT Gramedia Pustaka Utama.

10. Soekartawi. (1990). Prinsip Dasar Perencanaan Pembangunan, dengan Pokok Bahasan Khusus Perencanaan Pembangunan Daerah. Jakarta: Rajawali.

11. Thoha, Miftah. (2010). IImu Administrasi Publik Kontemporer. Jakarta: Kencana Predana Media Group.

12. Tjokroamidjojo, Bintoro. (1995a). Pengantar Administrasi Pembangunan. Jakarta: Pustaka LP3ES.

13. Tjokroamidjojo, Bintoro. (1995b). Perencanaan Pembangunan. Jakarta: PT Toko Gunung Agung. 